\title{
Reactions of the (2-Pyridyl) Pyrrolide Platinum(II) Complex Driven by Sterically Encumbered Chelation: A Model for the Reversible Attack of Alcohol at the Coordinated Carbon Monoxide
}

\author{
Jing-Lin Chen, ${ }^{\dagger}$ Chen-Huey Lin, ${ }^{\dagger}$ Jian-Hong Chen, ${ }^{\dagger}$ Yun Chi, ${ }^{,,}{ }^{\dagger}$ Yuan-Chieh Chiu, ${ }^{\dagger}$ Pi-Tai Chou, ${ }^{*, \neq}$ \\ Cheng-Hsuan Lai, ${ }^{\ddagger}$ Gene-Hsiang Lee, ${ }^{\ddagger}$ and Arthur J. Carty*,\$ \\ Department of Chemistry, National Tsing Hua University, Hsinchu 300, Taiwan, Department of \\ Chemistry and Instrumentation Center, National Taiwan University, Taipei 106, Taiwan, and \\ Steacie Institute for Molecular Sciences, National Research Council, Ottawa, Ontario K1A OR6, \\ Canada
}

Received January 22, 2008

\begin{abstract}
Treatment of 3,5-bis(trifluoromethyl)-2-(2'-pyridyl)pyrrole (fpyroH) with Pt(DMSO $)_{2} \mathrm{Cl}_{2}$ and $\mathrm{Na}_{2} \mathrm{CO}_{3}$ in THF solution gave a light-yellow complex denoted as [Pt(fpyro $\left.)_{2}\right](1)$. A single-crystal $\mathrm{X}$-ray diffraction study on 1 revealed a large conformational distortion around the platinum(II) center, which is attributed to interligand repulsion between the pyridyl groups and the $\mathrm{CF}_{3}$ substituents of the nearby pyrrolides. Reaction of 1 with $\mathrm{N}$ - and $\mathrm{C}$-donor ligands such as acetonitrile, pyridine, isocyanide, and $\mathrm{CO}$ affords the adducts $\left[\mathrm{Pt}(\mathrm{fpyro})_{2}(\mathrm{~L})\right], \mathrm{L}=\mathrm{NCMe}(2)$, pyridine (3), $\mathrm{CNBu}^{t}(4)$, and $\mathrm{CO}(5)$, showing formation of one monodentate fpyro ligand by release of the strain energy. The variable-temperature ${ }^{1} \mathrm{H}$ NMR studies showed a static structure for the $\mathrm{N}$-substituted adducts $\mathbf{2}$ and $\mathbf{3}$, whereas the C-adducts $\mathbf{4}$ and $\mathbf{5}$ are shown to be more labile, displaying a pairwise exchange of bidentate and monodentate fpyro ligands in solution. Addition of ethanol to the coordinated $\mathrm{CO}$ in $\mathbf{5}$ during recrystallization is also established, affording an ethoxycarbonyl complex [Pt(fpyro)(fpyroH) $\left.\left(\mathrm{CO}_{2} \mathrm{Et}\right)\right](6)$, which was isolated as a crystalline solid and can be readily converted back to 5 and free ethanol upon dissolution at room temperature.
\end{abstract}

\section{Introduction}

It has been reported that alkoxycarbonyl metal complexes with $[\mathrm{M}]-\mathrm{CO}_{2} \mathrm{R}$ subunits play an important role in diverse synthetic organic and organometallic processes such as esterification of alkenes, ${ }^{1}$ catalytic carbonylation, ${ }^{2}$ and nucleophilic activation of carbon monoxide. ${ }^{3}$ As a result, they have become a prime subject of various studies, including theoretical analyses. ${ }^{4}$ Such complexes are usually prepared from carbon monoxide together with isolated or in situ generated metal alkoxides, for which the reactions are

* To whom correspondence should be addressed. Fax: +1 6139537592 ; E-mail: carty.arthur@sympatico.ca (A.J.C.), Fax: +886 35720864 ; ychi@mx.nthu.edu.tw (Y.C.), Fax: +886 22369 5208; chop@ntu.edu.tw (P.-T.C.)

National Tsing Hua University.

National Taiwan University.

$\$$ National Research Council.

(1) (a) Kalck, P.; Urrutigoity, M.; Dechy-Cabaret, O. Top. Organomet. Chem. 2006, 18, 97. (b) Liu, J.; Heaton, B. T.; Iggo, J. A.; Whyman, R.; Bickley, J. F.; Steiner, A. Chem.-Eur. J. 2006, 12, 4417. (c) Nishihara, Y.; Miyasaka, M.; Inoue, Y.; Yamaguchi, T.; Kojima, M.; Takagi, K. Organometallics 2007, 26, 4054.

(2) Milstein, D. Acc. Chem. Res. 1988, 21, 428.

5154 Inorganic Chemistry, Vol. 47, No. 12, 2008 believed to proceed by $\mathrm{CO}$ migratory insertion into the $\mathrm{M}-\mathrm{O}$ bond. ${ }^{5}$ Notable literature precedence involves the hydroalkoxycarbonylation of alkenes and alkene-CO copolymerization catalyzed by palladium(II) metal catalysts, for which the formation of carboalkoxy intermediates by $\mathrm{CO}$ insertion into the Pd-methoxy fragment was established. ${ }^{6}$ Subsequently, propagation proceeded by multiple alternating insertions of $\mathrm{CO}$ and alkene, whereas termination occurs by methanolysis of the so-called $\beta$-chelate intermediate species to release the organic fragment and regenerate the $\mathrm{Pd}-$ methoxy complex. $^{1 \mathrm{~b}, 7}$ Moreover, the alkoxycarbonyl complexes $\left[\mathrm{Pd}(\mathrm{L}-\mathrm{L})\left(\mathrm{C}_{6} \mathrm{~F}_{5}\right)\right.$ $\left.\left(\mathrm{CO}_{2} \mathrm{R}\right)\right][(\mathrm{L}-\mathrm{L})=$ bis(3,5-dimethylpyrazol-1-yl)methane were also obtained from reaction of $\left[\mathrm{Pd}(\mathrm{L}-\mathrm{L})\left(\mathrm{C}_{6} \mathrm{~F}_{5}\right) \mathrm{Cl}\right]$ and aliphatic alcohol in the presence of $\mathrm{KOH}$, followed by in situ treatment with $\mathrm{CO}$ gas. ${ }^{8}$ On the other hand, although examples are rather limited, ${ }^{9}$ the possibility of the direct nucleophilic addition of the alkoxide anion to a metal-carbonyl has also been established. A third but even less common strategy would involve the direct treatment of alcohols with metal-carbonyl complexes in the absence of an externally 
added base. Because of the reduced nucleophilicity of the alcohols versus alkoxides, this reaction is restricted to strongly activated carbonyl complexes or the incorporation of a proton scavenger to shift the reaction in favor of the alkoxycarbonyl complexes.

In the present article, we extend the relevant synthetic study to a new platform involving a platinum(II) complex in which excessive steric interaction between distinctive chelating azolate ligands, namely 3,5-ditrifluoromethyl-2(2-pyridyl)pyrrole (fpyroH), activates the metal complexes such that facile ligand addition and carbonylation occur, and the subsequent reaction with alcohol can be monitored with spectroscopic methods. Moreover, this $\mathrm{CF}_{3}$-substituted 2-pyridyl pyrrolide ligand belongs to a class of novel nitrogenbased chelates that contain localized neutral and anionic donors, as exemplified by 2 -( $2^{\prime}$-pyridyl $)$ indole $^{10}$ and 3,5-ditbutyl-2-(2-pyridyl)pyrrole. ${ }^{11}$ Their platinum metal complexes show remarkable activity in various catalytic and stoichiometric transformations involving small hydrocarbyl fragments or even organic compounds. It is worthy noting that elegant work on chemistry of late transition-metal complexes employing other bidentate ligands such as 2-pyridylphosphines has been reported. ${ }^{12}$ In comparison, the chelating capability of 2-pyridyl pyrrolide (as monoanionic chelating ligands) is distinctive from those of 2-pyridylphosphines (best to act as neutral bridging ligands). The latter are very useful for the assembly of bimetallic compounds because the greater rigidity induced by the small bite angle favors the formation of metal-metal bonds. ${ }^{12}$

\section{Experimental Section}

General Information and Materials. Elemental analyses and mass spectra (operating in FAB mode) were carried out at the NSC Regional Instrument Centre at National Chiao Tung University, Taiwan. ${ }^{1} \mathrm{H}$ and ${ }^{13} \mathrm{C}$ NMR spectra were recorded on a Varian Mercury 400 or an Inova-500 MHz instrument; chemical shifts are quoted with respect to internal standard $\mathrm{Me}_{4} \mathrm{Si}$. All reagents and solvents were used as received, and all synthetic manipulations were performed under a $\mathrm{N}_{2}$ atmosphere.

(3) (a) Ford, P. C.; Rockiki, A. Adv. Organomet. Chem. 1988, 154, 323. (b) Katz, N. E.; Szalda, D. J.; Chou, M. H.; Creutz, C.; Sutin, N. J. Am. Chem. Soc. 1989, 111, 6591. (c) Felice, V. D.; De Renzi, A.; Ferrara, M. L.; Panunzi, A. J. Organomet. Chem. 1996, 513, 97.

(4) MacGregor, S. A.; Neave, G. W. Organometallics 2004, 23, 891.

(5) (a) Santi, R.; Romano, A. M.; Garrone, R.; Millini, R. J. Organomet. Chem. 1998, 566, 37. (b) Dockter, D. W.; Fanwick, P. E.; Kubiak, C. P. J. Am. Chem. Soc. 1996, 118, 4846 .

(6) Cavinato, G.; Vavasori, A.; Toniolo, L.; Benetollo, F. Inorg. Chim. Acta 2003, 343, 183.

(7) Liu, J.; Heaton, B. T.; Iggo, J. A.; Whyman, R. Angew. Chem., Int. Ed. 2004, 43, 90 .

(8) Ruiz, J.; Martinez, M. T.; Florenciano, F.; Rodriguez, V.; Lopez, G.; Perez, J.; Chaloner, P. A.; Hitchcock, P. B. Inorg. Chem. 2003, 42, 3650.

(9) (a) Sellin, M.; Luart, D.; Salauen, J.-Y.; Laurent, P.; Toupet, L.; Des Abbayes, H. Organometallics 1996, 15, 521. (b) Vasapollo, G.; Toniolo, L.; Cavinato, G.; Bigoli, F.; Lanfranchi, M.; Pellinghelli, M. A. J. Organomet. Chem. 1994, 481, 173. (c) Carmona, D.; Lahoz, F. J.; Oro, L. A.; Reyes, J.; Pilar Lamata, M. J. Chem. Soc., Dalton Trans. 1990, 3551.

(10) Karshtedt, D.; McBee, J. L.; Bell, A. T.; Tilley, T. D. Organometallics 2006, 25, 1801.

(11) Luedtke, A. T.; Goldberg, K. I. Inorg. Chem. 2007, 46, 8496.

(12) (a) Casares, J. A.; Espinet, P.; Martin-Alvarez, J. M.; Santos, V. Inorg. Chem. 2004, 43, 189. (b) Casares, J. A.; Espinet, P.; Martin-Alvarez, J. M.; Santos, V. Inorg. Chem. 2006, 45, 6628.
Synthesis of $\left[\mathbf{P t}(\mathbf{f p y r o})_{2}\right]$ (1). 3,5-Di(trifluoromethyl)-2-(2'pyridyl)pyrrole (fpyroH, $137 \mathrm{mg}, 0.48 \mathrm{mmol}), \mathrm{Pt}(\mathrm{DMSO})_{2} \mathrm{Cl}_{2}(100$ $\mathrm{mg}, 0.24 \mathrm{mmol})$, and $\mathrm{Na}_{2} \mathrm{CO}_{3}(0.49 \mathrm{~g}, 4.8 \mathrm{mmol})$ were added into $30 \mathrm{~mL}$ of THF, and the solution was refluxed for $12 \mathrm{~h}$. The solvent was then evaporated under vacuum, and $60 \mathrm{~mL}$ of ethyl acetate was added to extract the product. The organic layer was then washed with brine, dried over anhydrous $\mathrm{Na}_{2} \mathrm{SO}_{4}$, and concentrated to dryness, giving a yellow solid. Further purification was conducted using silica gel column chromatography eluting with a mixture of ethyl acetate and hexane (2:1), followed by vacuum sublimation $\left(120^{\circ} \mathrm{C}, 220 \mathrm{mTorr}\right)$, giving $\left[\mathrm{Pt}(\mathrm{fpyro})_{2}\right]$ as greenish-yellow crystals (70 mg, $0.93 \mathrm{mmol}, 40 \%$ ).

Spectral data of 1: MS(FAB) observed (actual) [assignment]: $m / z, 754(754)\left[\mathrm{M}^{+}\right], 735$ (735) $\left[\mathrm{M}^{+}-\mathrm{F}\right] .{ }^{1} \mathrm{H}$ NMR $\left(400 \mathrm{MHz}, d_{6^{-}}\right.$ acetone, $298 \mathrm{~K}$ ): py $\delta 8.76\left(\mathrm{~d}, J_{\mathrm{HH}}=5.6 \mathrm{~Hz}, 2 \mathrm{H}, \mathrm{CH}\right), 8.32\left(\mathrm{t}, J_{\mathrm{HH}}\right.$ $=8.0 \mathrm{~Hz}, 2 \mathrm{H}, \mathrm{CH}), 8.00\left(\mathrm{~d}, J_{\mathrm{HH}}=8.0 \mathrm{~Hz}, 2 \mathrm{H}, \mathrm{CH}\right), 7.48\left(\mathrm{t}, J_{\mathrm{HH}}\right.$ $=5.6 \mathrm{~Hz}, 2 \mathrm{H}, \mathrm{CH})$, pyro $7.14(\mathrm{~s}, 2 \mathrm{H}) .{ }^{19} \mathrm{~F}$ NMR $\left(470 \mathrm{MHz}, d_{6^{-}}\right.$ acetone, $298 \mathrm{~K}): \delta-52.81\left(\mathrm{~s}, \mathrm{CF}_{3}\right),-56.47\left(\mathrm{~s}, \mathrm{CF}_{3}\right)$. Anal. Calcd for $\mathrm{C}_{22} \mathrm{H}_{10} \mathrm{~F}_{12} \mathrm{~N}_{4} \mathrm{Pt}$ : C, 35.07; H, 1.34; N, 7.44. Found: C, 35.02; $\mathrm{H}, 1.29 ; \mathrm{N}, 7.32$.

Synthesis of $\left[\mathrm{Pt}(\mathrm{fpyro})_{2}(\mathrm{NCMe})\right]$ (2). On a $5 \mathrm{~mm}$ NMR tube, $1(10 \mathrm{mg})$ was dissolved in $0.5 \mathrm{~mL}$ of $d_{3}$-acetontrile by gentle heating. Although there was no obvious change of color, the NMR analysis showed only the signals attributed to $\mathbf{2}$; however, upon evaporation of $d_{3}$-acetonitrile and dissolution of the residue in $d_{6^{-}}$ acetone, further NMR analysis showed the regeneration of $\mathbf{1}$ without decomposition.

Spectral data of $2 .{ }^{1} \mathrm{H}$ NMR $\left(400 \mathrm{MHz}, d_{3}\right.$-acetonitrile, 298 K): py $\delta 8.44\left(\mathrm{~d}, J_{\mathrm{HH}}=7.5 \mathrm{~Hz}, 1 \mathrm{H}, \mathrm{CH}\right), 7.99\left(\mathrm{td}, J_{\mathrm{HH}}=8.2 \mathrm{~Hz}\right.$, $\left.J_{\mathrm{HH}}=1.4 \mathrm{~Hz}, 1 \mathrm{H}, \mathrm{CH}\right), 7.79\left(\mathrm{~d}, J_{\mathrm{HH}}=8.2 \mathrm{~Hz}, 1 \mathrm{H}, \mathrm{CH}\right), 7.75(\mathrm{td}$, $\left.J_{\mathrm{HH}}=7.4,1.2 \mathrm{~Hz}, 1 \mathrm{H}, \mathrm{CH}\right), 7.62\left(\mathrm{~d}, J_{\mathrm{HH}}=8.2 \mathrm{~Hz}, 1 \mathrm{H}, \mathrm{CH}\right)$, $7.30 \sim 7.26(\mathrm{~m}, 2 \mathrm{H}, \mathrm{CH}), 7.13\left(\mathrm{ddd}, J_{\mathrm{HH}}=7.5,7.4,1.2 \mathrm{~Hz}, 1 \mathrm{H}\right.$, $\mathrm{CH})$, pyro $7.01(\mathrm{~s}, 1 \mathrm{H}, \mathrm{CH}), 6.92(\mathrm{~s}, 1 \mathrm{H}, \mathrm{CH}) .{ }^{19} \mathrm{~F} \mathrm{NMR}(470 \mathrm{MHz}$, $d_{3}$-acetonitrile, $\left.298 \mathrm{~K}\right): \delta-54.01\left(\mathrm{~s}, \mathrm{CF}_{3}\right),-56.55\left(\mathrm{~s}, \mathrm{CF}_{3}\right),-58.43$ $\left(\mathrm{s}, \mathrm{CF}_{3}\right),-58.70\left(\mathrm{~s}, \mathrm{CF}_{3}\right)$.

Synthesis of [Pt(fpyro $\left.)_{2}(\mathbf{p y})\right]$ (3). A solution of $\mathbf{1}(20 \mathrm{mg}, 0.027$ mmol) and excess of pyridine $(8.8 \mu \mathrm{L}, 0.216 \mathrm{mmol})$ in $10 \mathrm{~mL}$ of acetone was stirred at room temperature for $30 \mathrm{~min}$. The solvent was removed using a rotary evaporator, and the residue recrystallized in a mixture of ethyl acetate and pentane, giving $20.5 \mathrm{mg}$ of green crystalline solid $(0.025 \mathrm{mmol}, 93 \%)$.

Spectral data of 3. MS(FAB) observed (actual) [assignment]: $\mathrm{m} / \mathrm{z} 833(833)\left[\mathrm{M}^{+}\right], 753(753)\left[\mathrm{M}^{+}\right.$-py]. ${ }^{1} \mathrm{H}$ NMR $\left(400 \mathrm{MHz}, d_{6^{-}}\right.$ acetone, $298 \mathrm{~K})$ py $\delta 8.83\left(\mathrm{~d}, J_{\mathrm{HH}}=6.0 \mathrm{~Hz}, 1 \mathrm{H}, \mathrm{CH}\right), 8.66\left(\mathrm{~d}, J_{\mathrm{HH}}\right.$ $=4.8 \mathrm{~Hz}, 1 \mathrm{H}, \mathrm{CH}), 8.20\left(\mathrm{t}, J_{\mathrm{HH}}=7.8 \mathrm{~Hz}, 1 \mathrm{H}, \mathrm{CH}\right), 8.12\left(\mathrm{~d}, J_{\mathrm{HH}}\right.$ $=6.0 \mathrm{~Hz}, 1 \mathrm{H}, \mathrm{CH}), 7.80 \sim 7.92(\mathrm{~m}, 2 \mathrm{H}, \mathrm{CH}), 7.84\left(\mathrm{t}, J_{\mathrm{HH}}=7.8\right.$ $\mathrm{Hz}, 1 \mathrm{H}, \mathrm{CH}), 7.57 \sim 7.50(\mathrm{~m}, 2 \mathrm{H}, \mathrm{CH}), 7.45\left(\mathrm{~d}, J_{\mathrm{HH}}=5.6 \mathrm{~Hz}, 1 \mathrm{H}\right.$, $\mathrm{CH}), 7.40\left(\mathrm{dd}, J_{\mathrm{HH}}=7.6,4.8 \mathrm{~Hz}, 1 \mathrm{H}, \mathrm{CH}\right), 7.32\left(\mathrm{t}, J_{\mathrm{HH}}=6.8 \mathrm{~Hz}\right.$, $2 \mathrm{H}, \mathrm{CH})$, pyro $6.80(\mathrm{~s}, 2 \mathrm{H}, \mathrm{CH}) .{ }^{19} \mathrm{~F}$ NMR $\left(470 \mathrm{MHz}, d_{6}\right.$-acetone, $298 \mathrm{~K}): \delta-53.67\left(\mathrm{~s}, \mathrm{CF}_{3}\right),-56.27\left(\mathrm{~s}, \mathrm{CF}_{3}\right),-57.46\left(\mathrm{~s}, \mathrm{CF}_{3}\right)$, $-58.57\left(\mathrm{~s}, \mathrm{CF}_{3}\right)$. Anal. Calcd for $\mathrm{C}_{27} \mathrm{H}_{15} \mathrm{~F}_{12} \mathrm{~N}_{5} \mathrm{Pt}$ : C, $38.95 ; \mathrm{H}, 1.82$; N, 8.41. Found: C, 39.13; H, 2.35; N, 8.18.

Synthesis of $\left.\left[\mathbf{P t}(\mathbf{f p y r o})_{2}(\mathbf{C N B u})^{t}\right)\right](4)$. A solution of $\mathbf{1}(20 \mathrm{mg}$, $0.027 \mathrm{mmol})$ and $t$-butyl isocyanide $(7.2 \mu \mathrm{L}, 0.054 \mathrm{mmol})$ in 10 $\mathrm{mL}$ of acetone was stirred at room temperature for $30 \mathrm{~min}$. The solvent was removed under vacuum, and the residue recrystallized in a mixture of ethyl acetate and pentane, giving $16 \mathrm{mg}$ of green crystalline solid $(0.020 \mathrm{mmol}, 74 \%)$. Single crystals of $\mathbf{4}$ suitable for X-ray diffraction study were obtained from a mixture of ethyl acetate and hexane at room temperature.

Spectral data of 4. MS(FAB) observed (actual) [assignment]: $m / z 836(836)\left[\mathrm{M}^{+}\right], 750(750)\left[\mathrm{M}^{+}\right.$- isobutene]. ${ }^{1} \mathrm{H}$ NMR (400 $\mathrm{MHz}, d_{6}$-acetone, $\left.298 \mathrm{~K}\right)$ : py $\delta 8.11(\mathrm{br}, 2 \mathrm{H}, \mathrm{CH}), 8.04\left(\mathrm{t}, J_{\mathrm{HH}}=\right.$ 
Chen et al.

Table 1. Crystal Data and Refinement Parameters for 1, 3, 4, and $\mathbf{6}$

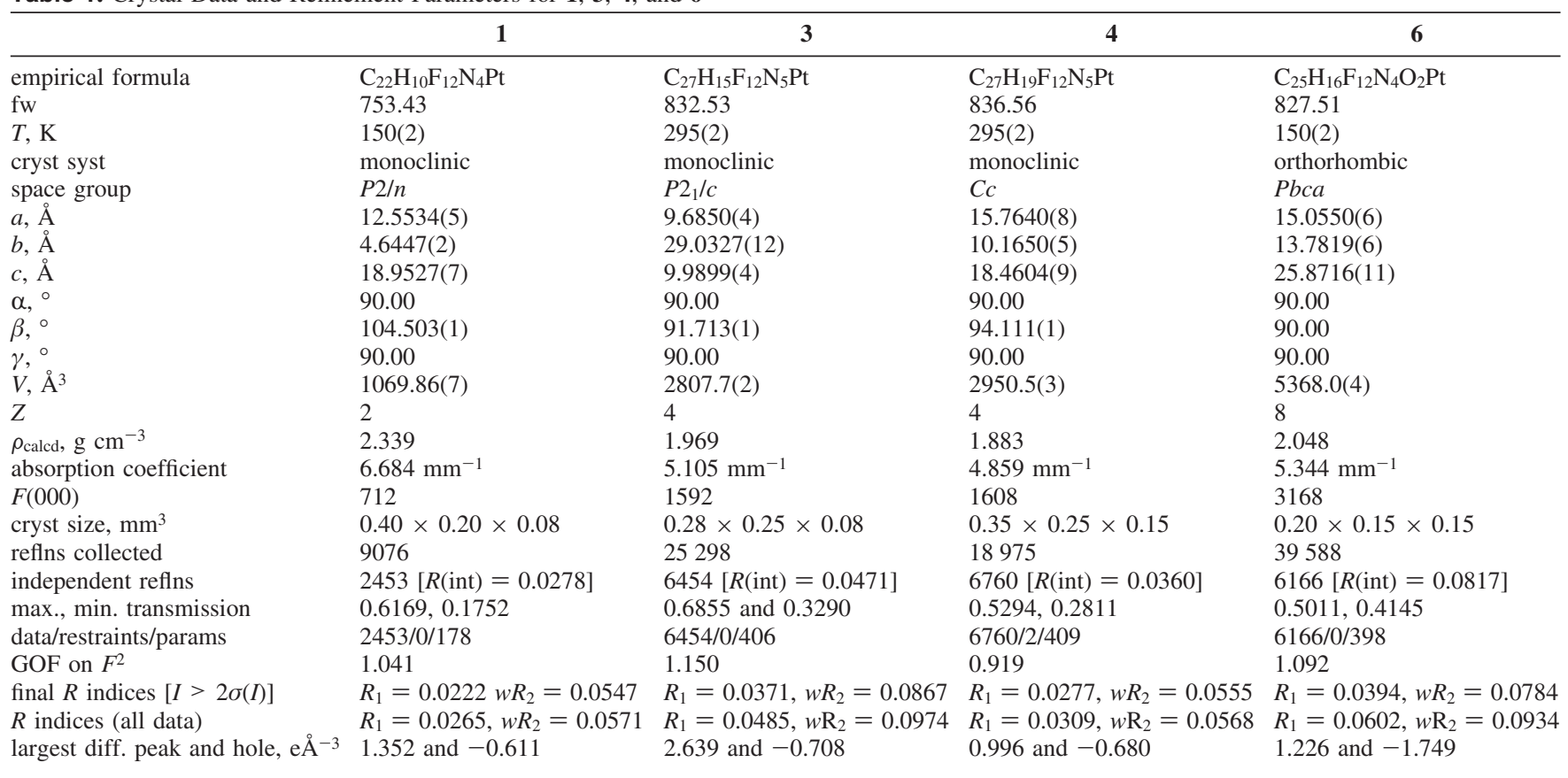

$8.0 \mathrm{~Hz}, 2 \mathrm{H}, \mathrm{CH}), 7.80\left(\mathrm{~d}, J_{\mathrm{HH}}=8.0 \mathrm{~Hz}, 2 \mathrm{H}, \mathrm{CH}\right), 7.39\left(\mathrm{t}, J_{\mathrm{HH}}=\right.$ $6.4 \mathrm{~Hz}, 2 \mathrm{H}, \mathrm{CH})$, pyro $6.98(\mathrm{~s}, 2 \mathrm{H}, \mathrm{CH}), 1.41(\mathrm{~s}, 9 \mathrm{H}, t-\mathrm{Bu}) .{ }^{19} \mathrm{~F}$ NMR $\left(470 \mathrm{MHz}, d_{6}\right.$-acetone, $\left.298 \mathrm{~K}\right): \delta-55.25\left(\mathrm{~s}, \mathrm{CF}_{3}\right),-58.17$ $\left(\mathrm{s}, \mathrm{CF}_{3}\right) .{ }^{19} \mathrm{~F} \mathrm{NMR}\left(470 \mathrm{MHz}, d_{6}\right.$-acetone, $\left.193 \mathrm{~K}\right): \delta-53.34(\mathrm{~s}$, $\left.\mathrm{CF}_{3}\right),-56.26\left(\mathrm{~s}, \mathrm{CF}_{3}\right),-57.43\left(\mathrm{~s}, \mathrm{CF}_{3}\right),-58.41\left(\mathrm{~s}, \mathrm{CF}_{3}\right)$. IR $\left(\mathrm{CHCl}_{3}\right): v(\mathrm{~N} \equiv \mathrm{C}) 2239$ (s) $\mathrm{cm}^{-1}$. Anal. Calcd for $\mathrm{C}_{27} \mathrm{H}_{19} \mathrm{~F}_{12} \mathrm{~N}_{5} \mathrm{Pt}$ : C, 38.77; H, 2.29; N, 8.37. Found: C, 39.03; H, 2.97; N, 8.32.

Synthesis of $\left[\mathbf{P t}(\mathbf{f p y r o})_{2}(\mathbf{C O})\right](5)$. On a $5 \mathrm{~mm}$ NMR tube, 1 $\left(10 \mathrm{mg}\right.$ ) was first dissolved in $0.5 \mathrm{~mL}$ of $d_{6}$-acetone. $\mathrm{CO}$ gas was then bubbled into this solution, and the color of the solution changed instantly from green to colorless, showing formation of the $\mathrm{CO}$ adduct 5. For the larger scale preparation, the solid sample of $\mathbf{5}$ was obtained by evaporation of acetone under vacuum at room temperature.

Spectral data of 5. MS(FAB) observed (actual) [assignment]: $m / z 781(782)\left[\mathrm{M}^{+}\right], 754(754)\left[\mathrm{M}^{+}-\mathrm{CO}\right] .{ }^{1} \mathrm{H}$ NMR $(500 \mathrm{MHz}$, $d_{6}$-acetone, $\left.298 \mathrm{~K}\right)$ : py $\delta 8.10\left(\mathrm{t}, J_{\mathrm{HH}}=7.8 \mathrm{~Hz}, 2 \mathrm{H}, \mathrm{CH}\right), 7.90(\mathrm{~d}$, $\left.J_{\mathrm{HH}}=7.8 \mathrm{~Hz}, 2 \mathrm{H}, \mathrm{CH}\right), 7.84\left(\mathrm{~d}, J_{\mathrm{HH}}=5.8 \mathrm{~Hz}, 2 \mathrm{H}, \mathrm{CH}\right), 7.44(\mathrm{t}$, $\left.J_{\mathrm{HH}}=5.8 \mathrm{~Hz}, 2 \mathrm{H}, \mathrm{CH}\right)$, pyro $7.14(\mathrm{~s}, 2 \mathrm{H}, \mathrm{CH}) .{ }^{19} \mathrm{~F}$ NMR $(470$ $\mathrm{MHz}, d_{6}$-acetone, $\left.298 \mathrm{~K}\right): \delta-55.66\left(\mathrm{~s}, \mathrm{CF}_{3}\right),-58.36\left(\mathrm{~s}, \mathrm{CF}_{3}\right) .{ }^{19} \mathrm{~F}$ NMR data $\left(470 \mathrm{MHz}, \mathrm{d}_{6}\right.$-acetone, $\left.193 \mathrm{~K}\right): \delta-55.40\left(\mathrm{~s}, \mathrm{CF}_{3}\right)$, -58.04 (s, $\left.\mathrm{CF}_{3}\right)$. IR (solid): $v(\mathrm{C} \equiv \mathrm{O}) 2102$ (s, sh), $2090(\mathrm{~s}) \mathrm{cm}^{-1}$.

Synthesis of [Pt(fpyro)(fpyroH)(CO $\left.\left.\mathbf{C O}_{2} \mathbf{E t}\right)\right](6) .1$ (100 mg) was first dissolved in $6 \mathrm{~mL}$ of acetone. Then, $\mathrm{CO}$ gas was then bubbled into this solution, and the color of the solution changed instantly from light-green to colorless. After $10 \mathrm{~min}$, the solution was concentrated by blowing off the solvent under a fast stream of $\mathrm{CO}$ gas. The residue was then recrystallized from a mixture of ethanol and acetone, giving $70 \mathrm{mg}$ of light-yellow crystalline solids $(0.085$ mmol, 64\%).

Spectral data of $6 .{ }^{1} \mathrm{H}$ NMR data $\left(500 \mathrm{MHz}, d_{6}\right.$-acetone, $\left.193 \mathrm{~K}\right)$ : $\delta 19.19\left(\mathbf{6}, \mathrm{d}, J_{\mathrm{HF}}=5.0 \mathrm{~Hz}, 1 \mathrm{H}, \mathrm{NH}\right), 4.26\left(\mathbf{6}, \mathrm{m}, 1 \mathrm{H}, \mathrm{CH}_{2}\right), 4.14$ $\left(\mathrm{t}, J_{\mathrm{HH}}=5.0 \mathrm{~Hz}, 1 \mathrm{H}, \mathrm{OH}\right.$ of EtOH), $3.97\left(\mathbf{6}, \mathrm{m}, 1 \mathrm{H}, \mathrm{CH}_{2}\right), 3.50$ $\left(\mathrm{m}, 2 \mathrm{H}, \mathrm{CH}_{2} \mathrm{O}\right.$ of EtOH$), 1.15\left(6, \mathrm{t}, J_{\mathrm{HH}}=7.0 \mathrm{~Hz}, 3 \mathrm{H}, \mathrm{Me}\right), 1.05$ $\left(\mathrm{t}, J_{\mathrm{HH}}=7.0 \mathrm{~Hz}, 3 \mathrm{H}, \mathrm{Me}\right.$ of EtOH$) .{ }^{19} \mathrm{~F} \mathrm{NMR}$ data $(470 \mathrm{MHz}$, $d_{6}$-acetone, $\left.193 \mathrm{~K}\right): \delta-53.15\left(\mathbf{6}, \mathrm{CF}_{3}\right),-55.38\left(\mathbf{5}, \mathrm{CF}_{3}\right),-56.09$ $\left(6, \mathrm{CF}_{3}\right),-57.51\left(5, \mathrm{CF}_{3}\right),-58.01\left(6, \mathrm{CF}_{3}\right),-59.28\left(6, \mathrm{CF}_{3}\right)$. Anal. Calcd for $\mathrm{C}_{25} \mathrm{H}_{16} \mathrm{O}_{2} \mathrm{~F}_{12} \mathrm{~N}_{4} \mathrm{Pt}$ : C, 36.29; H, 1.95; N, 6.77. Found: $\mathrm{C}$, $36.08 ; \mathrm{H}, 2.18 ; \mathrm{N}, 6.73$.
Synthesis of [Pt(fpyro)(fpyroH)(CO) $\left.\left.\mathbf{C O}_{2} \mathbf{M e}\right)\right](7) .1(100 \mathrm{mg})$ was dissolved in $6 \mathrm{~mL}$ of acetone. Then, $\mathrm{CO}$ gas was then bubbled into this solution, and the color of solution changed instantly from lightgreen to colorless. After $10 \mathrm{~min}$, the solution was concentrated by increasing the flow rate of $\mathrm{CO}$ gas. The solid residue was then recrystallized from a mixture of methanol and acetone, giving 95 $\mathrm{mg}$ of light-green crystalline solids $(0.12 \mathrm{mmol}, 88 \%)$.

Spectral data of $7 .{ }^{1} \mathrm{H} \mathrm{NMR}$ data $\left(500 \mathrm{MHz}, d_{6}\right.$-acetone, $\left.193 \mathrm{~K}\right)$ : $\delta 19.09\left(7, \mathrm{~d}, J_{\mathrm{HF}}=5.0 \mathrm{~Hz}, 1 \mathrm{H}, \mathrm{NH}\right), 3.87\left(\mathrm{q}, J_{\mathrm{HH}}=5.0 \mathrm{~Hz}, 1 \mathrm{H}\right.$, $\mathrm{OH}$ of $\mathrm{MeOH}), 3.65(7, \mathrm{~s}, 3 \mathrm{H}, \mathrm{OMe}), 3.24\left(\mathrm{~d}, J_{\mathrm{HH}}=5.0 \mathrm{~Hz}, 3 \mathrm{H}\right.$, $\mathrm{OMe}$ of $\mathrm{MeOH}) .{ }^{19} \mathrm{~F}$ NMR $\left(470 \mathrm{MHz}, d_{6}\right.$-acetone, $\left.298 \mathrm{~K}\right): \delta$ $-55.69\left(\mathbf{5}, \mathrm{CF}_{3}\right),-58.39\left(\mathbf{5}, \mathrm{CF}_{3}\right)$. Lower temperature ${ }^{19} \mathrm{~F}$ NMR data $\left(470 \mathrm{MHz}, d_{6}\right.$-acetone, $\left.193 \mathrm{~K}\right): \delta-53.17\left(7, \mathrm{CF}_{3}\right),-55.38$ $\left(5, \mathrm{CF}_{3}\right),-56.09\left(7, \mathrm{CF}_{3}\right),-57.66\left(7, \mathrm{CF}_{3}\right),-58.01\left(5, \mathrm{CF}_{3}\right)$, $-59.36\left(7, \mathrm{CF}_{3}\right)$. Anal. Calcd for $\mathrm{C}_{24} \mathrm{H}_{14} \mathrm{O}_{2} \mathrm{~F}_{12} \mathrm{~N}_{4} \mathrm{Pt}$ : C, 35.44; $\mathrm{H}$, 1.73; N, 6.89. Found: C, 35.18; H, 1.96; N, 6.81.

X-ray Structural Measurements. Single-crystal X-ray analysis was carried out on a Bruker SMART Apex CCD diffractometer using $\mu($ Mo $K \alpha)$ radiation $(\lambda=0.71073 \AA)$. The data collection was executed using the SMART program. Cell refinement and data reduction were made by the SAINT program. The structure was determined using the SHELXTL/PC program and refined using fullmatrix least-squares. All non-hydrogen atoms were refined anisotropically, whereas hydrogen atoms were placed at the calculated positions and included in the final stage of refinements with fixed parameters. The crystallographic refinement parameters of $\mathbf{1 , 3}, \mathbf{4}$, and $\mathbf{6}$ are summarized in Table 1.

\section{Results and Discussion}

This project began with a goal of synthesizing materials with high luminous efficiency in the visible region. ${ }^{13}$ In this regard, we set out to examine the platinum(II) azolate complexes and their derivatives such as $\left[\mathrm{Pt}(\mathrm{pydz})_{2}\right]$ and [Pt(fppz $\left.)_{2}\right]$ (Chart 1), for which higher emission quantum yields have led to the successful fabrication of decent

(13) (a) Chou, P.-T.; Chi, Y. Chem.-Eur. J. 2007, 13, 380. (b) Chi, Y.; Chou, P.-T. Chem. Soc. Rev. 2007, 36, 1421. (c) Williams, J. A. G. Top. Curr. Chem. 2007, 281, 205. 


\section{Chart 1}
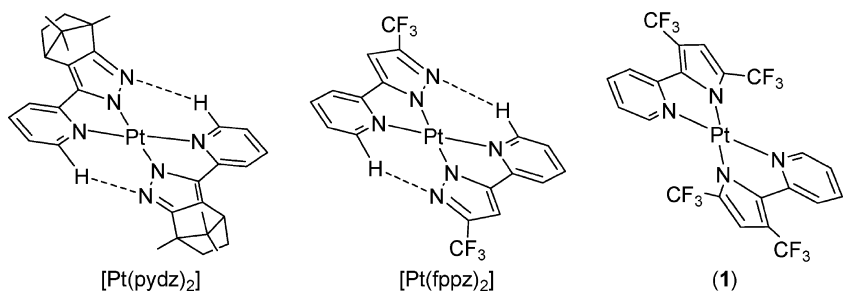

phosphorescent OLEDs. ${ }^{14}$ In these complexes, there exist a pair of $\mathrm{C}-\mathrm{H} \cdots \mathrm{N}$ interligand hydrogen bonding interactions between the adjacent pyridyl and azolate fragments, which provide an extra stabilization to the square-planar geometry. For further examination of the fundamental nature of these platinum(II) metal complexes, we proceeded to design and synthesize the 2-pyridyl pyrrolide complex [Pt(fpyro $\left.)_{2}\right](\mathbf{1})$, which is quite distinctive from its predecessors due to the highly encumbered chelates introduced. We believed that the $\mathrm{CF}_{3}$ substituents of the pyrrolide would exert a large steric interaction with the adjacent pyridyl unit; the resulting pyrrolide 1 was expected to adopt a distorted geometry ideally suited for investigation of the delicate reaction patterns, including ligand addition and even fluxional behavior.

First of all, the required 2-pyridyl pyrrole chelate (fpyro)H was synthesized in two steps by employing condensation of 2-aminomethylpyridine and hexafluoroacetylacetone, followed by dehydration using excess of concentrated $\mathrm{H}_{2} \mathrm{SO}_{4}$ at $180{ }^{\circ} \mathrm{C} .{ }^{15}$ The subsequent reaction of (fpyro)H with $\mathrm{Pt}(\mathrm{DMSO})_{2} \mathrm{Cl}_{2}$ in THF solution at reflux gave a light-yellow complex denoted as [Pt(fpyro $\left.)_{2}\right]$ (1) in good yield. Alternatively, 1 can be prepared from (fpyro) $\mathrm{H}$ and $\mathrm{K}_{2} \mathrm{PtCl}_{4}$ in a mixture of ethanol and water, but this suffers from an inferior product yield. Next, 1 was fully characterized using NMR spectroscopy and single crystal X-ray diffraction analysis to establish its molecular structure.

As depicted in Figure 1, the structure of $\mathbf{1}$ possesses a center of inversion that coincides with the platinum atom. At first glance, each chelating ligand adopts a severely distorted conformation, whereas the $\mathrm{Pt}-\mathrm{N}$ (pyrrolide) distances $(\mathrm{Pt}-\mathrm{N}(2)=2.037(4) \AA)$ are notably longer than those of the $\mathrm{Pt}-\mathrm{N}$ (pyridine) distances $(\mathrm{Pt}-\mathrm{N}(1)=2.013(3) \AA)$. This observation is in sharp contrast to the typical bonding pattern involving coordinated 2-pyridyl azolate fragments, for which the anionic azolate nitrogen atom tends to exhibit a much shorter bond distance versus that of the neutral pyridyl group ${ }^{16}$ due to the stronger Coulombic interaction between the transition-metal cation and the anionic $\mathrm{N}$-donor atoms. A similar correlation was also observed in the respective main-group complexes. ${ }^{17}$ As a result, the unusual variation of metric parameters in $\mathbf{1}$ reflects a significant

(14) (a) Kavitha, J.; Chang, S.-Y.; Chi, Y.; Yu, J.-K.; Hu, Y.-H.; Chou, P.-T.; Peng, S.-M.; Lee, G.-H.; Tao, Y.-T.; Chien, C.-H.; Carty, A. J. Adv. Funct. Mater. 2005, 15, 223. (b) Chang, S.-Y.; Kavitha, J.; Li, S.-W.; Hsu, C.-S.; Chi, Y.; Yeh, Y.-S.; Chou, P.-T.; Lee, G.-H.; Carty, A. J.; Tao, Y.-T.; Chien, C.-H. Inorg. Chem. 2006, 45, 137.

(15) (a) Klappa, J. J.; Rich, A. E.; McNeill, K. Org. Lett. 2002, 4, 435. (b) Ohkura, H.; Berbasov, D. O.; Soloshonok, V. A. Tetra. Lett. 2003, 44, 2417. weakening of metal-ligand bonding induced by the steric repulsion imposed by the $\mathrm{CF}_{3}$ substituents. It is also noteworthy that the shortest intermolecular Pt $\cdots$ Pt distance is calculated to be $\sim 4.645 \AA$ in the crystal lattice, which is beyond the range of direct $\mathrm{Pt}-\mathrm{Pt}$ interaction. ${ }^{18}$

In degassed acetone solution, $\mathbf{1}$ revealed a symmetrical ${ }^{1} \mathrm{H}$ NMR spectral pattern, implying the retention of the molecular structure observed in the solid state. In contrast, dissolution of $\mathbf{1}$ in acetonitrile produced a new platinum metal complex denoted as $\left[\mathrm{Pt}(\mathrm{fpyro})_{2}(\mathrm{NCMe})\right](\mathbf{2})$. Although 2 is somewhat less stable in solvents other than acetonitrile, its formation can be unambiguously confirmed by sequential addition of acetonitrile into a $d_{6}$-acetone solution of $\mathbf{1}$. As shown in Figure S1 of the Supporting Information, a new set of asymmetrical ${ }^{1} \mathrm{H}$ NMR signals emerged upon addition of 1 equiv of acetonitrile, whereas the ratio of $\mathbf{2}$ to $\mathbf{1}$ increases to 1:2.5 and 1:0.9 upon the addition of a total of 5 equiv and 20 equiv of acetonitrile, showing the gradual shifting of the equilibrium to $\mathbf{2}$, a result of rapid interconversion and a continuous increase of the relative concentration of acetonitrile donor reagent. Moreover, upon the dissolution of $\mathbf{1}$ into pure $d_{3}$-acetonitrile solvent, the ${ }^{1} \mathrm{H}$ NMR exhibited only the proton signals for 2 , whereas its ${ }^{19} \mathrm{~F}$ NMR spectrum at room temperature showed four singlets of equal intensity at $\delta-54.01,-56.55,-58.43$, and -58.70 , revealing the existence of two distinctive fpyro ligand environments. On the basis of these notable spectral features, we assigned a square-planar structure for $\mathbf{2}$, with one bidentate fpyro chelate being converted to the monodentate mode (Chart 2). However, this complex is rather unstable and labile in the absence of acetonitrile, confirmed by the rapid and quantitative regeneration of the symmetrical ${ }^{1} \mathrm{H}$ NMR spectral pattern expected for $\mathbf{1}$ upon the removal of acetonitrile in vacuo and redissolving the solid residue in non-coordinating solvents such as chloroform, acetone, or benzene.

To further confirm the structure of $\mathbf{2}$, the reaction of $\mathbf{1}$ with a stronger $\mathrm{N}$-donor, such as pyridine, was explored,

(16) (a) Wu, P.-C.; Yu, J.-K.; Song, Y.-H.; Chi, Y.; Chou, P.-T.; Peng, S.-M.; Lee, G.-H. Organometallics 2003, 22, 4938. (b) Hsu, F.-C.; Tung, Y.-L.; Chi, Y.; Hsu, C.-C.; Cheng, Y.-M.; Ho, M.-L.; Chou, P.-T.; Peng, S.-M.; Carty, A. J. Inorg. Chem. 2006, 45, 10188. (c) Chang, S.-Y.; Kavitha, J.; Hung, J.-Y.; Chi, Y.; Cheng, Y.-M.; Li, E. Y.; Chou, P.-T.; Lee, G.-H.; Carty, A. J. Inorg. Chem. 2007, 46, 7064. (d) Yang, C.-H.; Cheng, Y.-M.; Chi, Y.; Hsu, C.-J.; Fang, F.C.; Wong, K.-T.; Chou, P.-T.; Chang, C.-H.; Tsai, M.-H.; Wu, C.-C. Angew. Chem., Int. Ed. 2007, 46, 2418.

(17) (a) Liu, S.-F.; Wu, Q.; Schmider, H. L.; Aziz, H.; Hu, N.-X.; Popovic, Z.; Wang, S. J. Am. Chem. Soc. 2000, 122, 3671. (b) Cheng, C.-C.; Yu, W.-S.; Chou, P.-T.; Peng, S.-M.; Lee, G.-H.; Wu, P.-C.; Song, Y.-H.; Chi, Y. Chem. Commun. 2003, 2628. (c) Klappa, J. J.; Geers, S. A.; Schmidtke, S. J.; MacManus-Spencer, L. A.; McNeill, K. Dalton Trans. 2004, 883. (d) Chen, H.-Y.; Chi, Y.; Liu, C.-S.; Yu, J.-K.; Cheng, Y.-M.; Chen, K.-S.; Chou, P.-T.; Peng, S.-M.; Lee, G.-H.; Carty, A. J.; Yeh, S.-J.; Chen, C.-T. Adv. Funct. Mater. 2005, 15, 567. (e) Song, Y.-H.; Chiu, Y.-C.; Chi, Y.; Chou, P.-T.; Cheng, Y.M.; Lin, C.-W.; Lee, G.-H.; Carty, A. J. Organometallics 2008, 27,80 .

(18) (a) Kui, S. C. F.; Chui, S. S.-Y.; Che, C.-M.; Zhu, N. J. Am. Chem. Soc. 2006, 128, 8297. (b) Yu, C.; Wong, K. M.-C.; Chan, K. H.-Y.; Yam, V. W.-W. Angew. Chem., Int. Ed. 2005, 44, 791. (c) He, Z.; Wong, W.-Y.; Yu, X.; Kwok, H.-S.; Lin, Z. Inorg. Chem. 2006, 45, 10922. (d) Chang, S.-Y.; Chen, J.-L.; Chi, Y.; Cheng, Y.-M.; Lee, G.-H.; Jiang, C.-M.; Chou, P.-T. Inorg. Chem. 2007, 46, 11202. (e) Du, P.; Schneider, J.; Brennessel, W. W.; Eisenberg, R. Inorg. Chem. 2008, 47, 69 . 


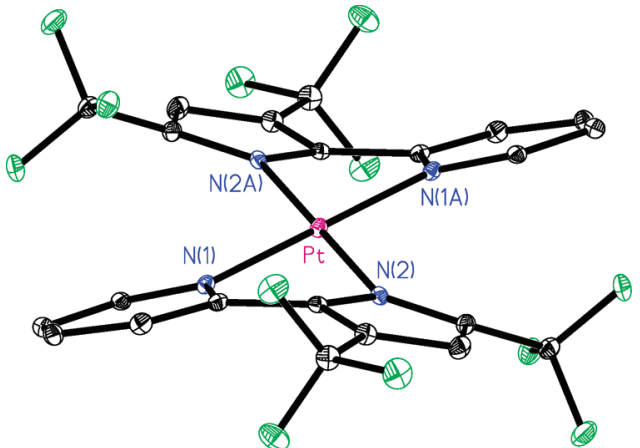

Figure 1. ORTEP diagram of $\mathbf{1}$ with ellipsoids shown at $25 \%$ probability level; selected bond distances: $\mathrm{Pt}-\mathrm{N}(1)=2.013(3)$ and $\mathrm{Pt}-\mathrm{N}(2)=2.037$ (4) $\AA$.

\section{Chart 2}

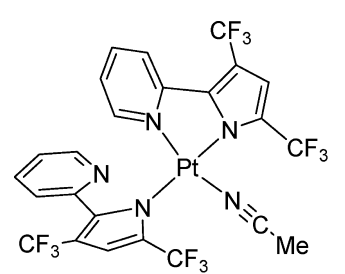

(2)

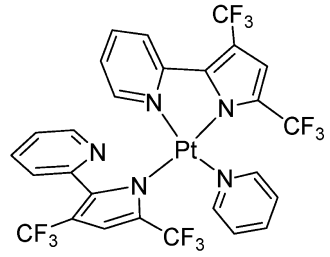

(3) giving $\left[\mathrm{Pt}(\mathrm{fpyro})_{2}(\mathrm{py})\right](3)$, which was isolated and purified using routine protocols. Single-crystal X-ray diffraction analysis of $\mathbf{3}$ showed incorporation of a single pyridine molecule and again, the conversion of one fpyro ligand into a monodentate mode with its uncoordinated pyridyl moiety hanging over the basal plane defined by the second, bidentate fpyro ligand (Figure 2). This bonding mode is reminiscent of the cationic complexes $[\mathrm{Pt}(\text { diimine })(\mathrm{ttcn})]^{2+}(\mathrm{ttcn}=1,4,7-$ trithiacyclononane) with a sulfur nucleophile residing adjacent to the vacant axial sites and displaying a critical role in ligand exchange and multiredox catalysis. ${ }^{19}$ It is believed that the release of internal strain between the pair of fpyro chelates in $\mathbf{3}$ is the main driving force that allows the successful addition of monodentate pyridine.

Moreover, the reaction of $\mathbf{1}$ with the carbon donor, $t$-butyl isocyanide afforded the related complex $\left[\mathrm{Pt}(\mathrm{fpyro})_{2}\left(\mathrm{CNBu}^{t}\right)\right]$ (4). Subsequent X-ray structural analysis (Figure 3) showed a similar framework with respect to the pyridine predecessor 3. In sharp contrast, whereas the ${ }^{19} \mathrm{~F}$ NMR spectrum of $\mathbf{4}$ showed four distinctive signals at $\delta-53.34,-56.26,-57.43$, and -58.41 at $-80{ }^{\circ} \mathrm{C}$ similar to those of $\mathbf{3}$ detected at all temperatures, the signals of $\mathbf{4}$ started to broaden upon increasing temperature and finally coalesced in sequence to

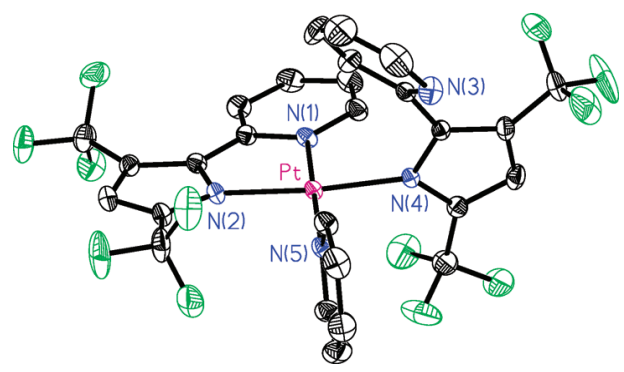

Figure 2. ORTEP diagram of $\mathbf{3}$ with ellipsoids shown at 20\% probability level; selected bond distances: $\mathrm{Pt}-\mathrm{N}(1)=2.009(4), \mathrm{Pt}-\mathrm{N}(2)=2.036(4)$, $\mathrm{Pt}-\mathrm{N}(4)=2.021(4)$, and $\mathrm{Pt}-\mathrm{N}(5)=2.026(4) \AA$.

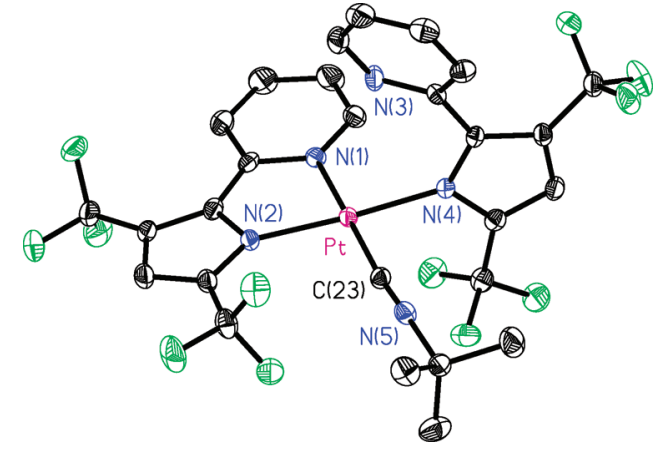

Figure 3. ORTEP diagram of $\mathbf{4}$ with ellipsoids shown at 20\% probability level; selected bond distances: $\mathrm{Pt}-\mathrm{C}(23)=1.919(5), \mathrm{Pt}-\mathrm{N}(1)=2.056(4)$, $\mathrm{Pt}-\mathrm{N}(2)=2.018(4), \mathrm{Pt}-\mathrm{N}(4)=2.039(4)$ and $\mathrm{Pt}-\mathrm{N}(3)=2.994(4) \AA$.

give two signals at $\delta-55.25$ and -58.17 at $25{ }^{\circ} \mathrm{C}$ (Figure S2 in the Supporting Information), showing solution dynamics that would require a time-averaged, indistinctive environment for both the bidentate and monodentate fpyro ligands. This transformation is graphically illustrated in Scheme 1 with a hypothetical TBP transition state.

We believe that this behavior correlates with the stronger $\sigma$-donating and $\pi$-accepting properties of the $\mathrm{C}$-donor ligand. The $\sigma$-donating character would weaken the $\mathrm{Pt}-\mathrm{N}$ vector trans to this isocyanide ligand. Indeed, the weakened $\mathrm{Pt}-\mathrm{N}$ (pyridine) bonding is illustrated in the solid state structures (cf. Pt $-\mathrm{N}(1)=2.056(4) \AA$ in 4 versus $\mathrm{Pt}-\mathrm{N}(1)$ $=2.008(4) \AA$ in 3). Alternatively, the better $\pi$-accepting properties of isocyanide may increase the coordinative unsaturation at the vacant axial site, making the associated platinum(II) complexes more accessible to the pendant pyridyl group to form a dative bonding interaction as well as to stabilize the excessive electron density at the central platinum atom in the transition state (Scheme 1). Thus, the synergism between the $\sigma$-donating and $\pi$-accepting properties of the isocyanide ligand makes $\mathbf{4}$ much more fluxional in solution. Furthermore, this concurrent on-and-off coordination fluxionality involving the trans-arranged pyridyl groups is somewhat analogous to those occurring in the transitionmetal complexes with 2-pyridylphosphine ligands, which are known to undergo pairwise exchange between the coordinated and pendant pyridyl groups. ${ }^{20}$

Analogously, 1 reacted with $\mathrm{CO}$ in acetone to afford a product in near quantitative yield at room temperature. This reaction has been monitored using NMR techniques and absorption spectroscopy during the CO titration (Figure S3 in the Supporting Information). Attempts to grow single crystals of the product in aprotic solvents unfortunately failed. Nevertheless, according to the reaction pattern discussed, it is reasonable to propose the formation of a $\mathrm{CO}$-adduct $\mathbf{5}$, for which the structure depicted in Scheme 2 is proposed. Note that the ATR FTIR spectrum of $\mathbf{5}$ in the solid state revealed an intense $v(\mathrm{CO})$ signal at $2090 \mathrm{~cm}^{-1}$ as well as a shoulder at $2102 \mathrm{~cm}^{-1}$ due to the Fermi resonance; both bands occurred within the spectral range reported for the

(19) Green, T. W.; Lieberman, R.; Mitchell, N.; Bauer, J. A. K.; Connick, W. B Inorg. Chem. 2005, 44, 1955.

(20) Espinet, P.; Hernando, R.; Iturbe, G.; Villafane, F.; Orpen, A. G.; Pascual, I. Eur. J. Inorg. Chem. 2000, 1031. 
Scheme 1<smiles></smiles>

(4)

\section{Scheme 2}

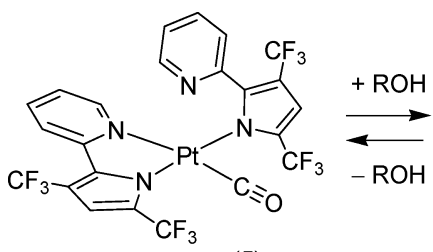

(5)

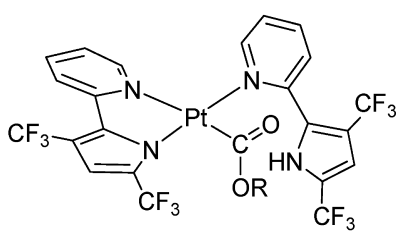

$R=E t(6) ; R=M e(7)$
Pt-CO fragment $\left(2109 \sim 2044 \mathrm{~cm}^{-1}\right)$ in the literature. ${ }^{21}$ Moreover, the ${ }^{19} \mathrm{~F}$ NMR analyses of 5 revealed two timeaveraged signals at $\delta-55.66$ and -58.36 at $25{ }^{\circ} \mathrm{C}$, which are akin to those of the isocyanide analogue 4 , even though 5 showed a much faster fluxional motion by exhibiting two sharp signals even at $-80{ }^{\circ} \mathrm{C}$, the lowest temperature that could be achieved in $d_{6}$-acetone solution.

Despite the failure to grow a single crystal of $\mathbf{5}$ in aprotic solvents, crystalline solids, denoted as $\mathbf{6}$, were obtained in $\sim 64 \%$ yield using a mixture of acetone-ethanol as the recrystallization solvent at room temperature. As revealed in the X-ray structure (Figure 4), ethanol has reacted with the coordinated $\mathrm{CO}$ ligand of $\mathbf{5}$ during recrystallization to afford the ethoxycarbonyl unit observed in 6. At the same time, transfer of the proton derived from ethanol to one pyrrolide generated the observed pendant pyrrole, in which the $\mathrm{N}-\mathrm{H}$ fragment strongly interacts with the carbonyl group via a short intramolecular hydrogen bond, $\mathrm{N}(2)-\mathrm{H}(2) \cdots \mathrm{O}(1)$ $=1.869 \AA$. Because of the concomitant detachment of this pyrrolide fragment, 6 still retained the square-planar coordination geometry anticipated for the majority of platinum(II) metal complexes.

The solution behavior of $\mathbf{6}$ is also fully consistent with the above proposed structural properties shown in Scheme 2. First, the ${ }^{1} \mathrm{H}$ and ${ }^{19} \mathrm{~F}$ NMR spectra of a vaccuum-dried sample of 6 in $d_{6}$-acetone showed all of the anticipated signals corresponding to an exactly 1:1 mixture of $\mathbf{5}$ and free ethanol at room temperature (lowest trace of spectra in Figure 5), confirming the rapid regeneration of ethanol and 5 upon dissolution of $\mathbf{6}$ in acetone at room temperature. This assignment was further confirmed by the observation of two equal intensity ${ }^{19} \mathrm{~F}$ NMR signals expected for $\mathbf{5}$ at the same temperature. Upon lowering the temperature to $-80{ }^{\circ} \mathrm{C}$, in addition to the signals ascribed to $\mathbf{5}$, the ${ }^{19} \mathrm{~F}$ NMR spectrum showed the emergence of four new $\mathrm{CF}_{3}$ signals at $\delta-53.2$, $-56.1,-57.5$, and -59.3 , which are clearly derived from 6

(21) (a) Mdleleni, M. M.; Bridgewater, J. S.; Watts, R. J.; Ford, P. C. Inorg Chem. 1995, 34, 2334. (b) Cave, G. W. V.; Fanizzi, F. P.; Deeth, R. J.; Errington, W.; Rourke, J. P. Organometallics 2000, 19, 1355. (c) Lu, W.; Roy, V. A. L.; Che, C.-M. Chem. Commun. 2006, 3972. with two distinctive fpyro ligands, showing that $\mathbf{6}$ becomes more favorable and is in equilibrium with $\mathbf{5}$ at lower temperature. Moreover, the ${ }^{1} \mathrm{H}$ NMR spectrum of $\mathbf{6}$ recorded at $-80{ }^{\circ} \mathrm{C}$ revealed two important features that support its structural characteristics. First, a highly deshielded proton signal at $\delta 19.18$ is resolved, which is reasonably attributed to the strongly hydrogen-bonded pyrrolic $\mathrm{N}-\mathrm{H}$ group. Second, there exist two multiplets at $\delta 4.24$ and 3.98, for which the chemical shifts and coupling pattern are consistent with the diasterotopic nature of the methylene protons in an ethoxycarbonyl group. Unfortunately, this transformation is complicated by the detection of another set of weak ${ }^{1} \mathrm{H}$ NMR signals at $\delta 15.52$ and four $\mathrm{CF}_{3}$ signals at $\delta-53.76,-56.09$, -58.15 , and -60.35 in the ${ }^{19} \mathrm{~F}$ NMR spectrum at $-80{ }^{\circ} \mathrm{C}$ (Figure $\mathrm{S} 4$ in the Supporting Information). The species showing such signals could result from an unknown structural isomer of ethoxycarbonyl 6; however, more experimental and spectroscopic data are required to fully decipher its true identity. Finally, upon further raising the temperature back to room temperature, $\mathbf{5}$ regained its dominance, together with a reduction in the concentration of $\mathbf{6}$ as well as the occurrence of partial sample decomposition. Most importantly, these spectroscopic features provided solid evidence for the delicate temperature-dependent equilibrium of the alcohol attack at the metal-carbonyl fragment.

This $\mathrm{CO}$ activation process is also extended to a full range of related reagents, which include methanol, benzyl alcohol, isopropyl alcohol, and tert-butyl alcohol. For the reaction with anhydrous methanol, a crystalline sample of $\mathbf{7}$ has been isolated and fully characterized via spectroscopic methods. Again, the results showed the rapid reversion to $\mathbf{5}$ and free methanol in $d_{6}$-acetone at room temperature; the solution spectra confirmed the existence of 5, methoxycarbonyl

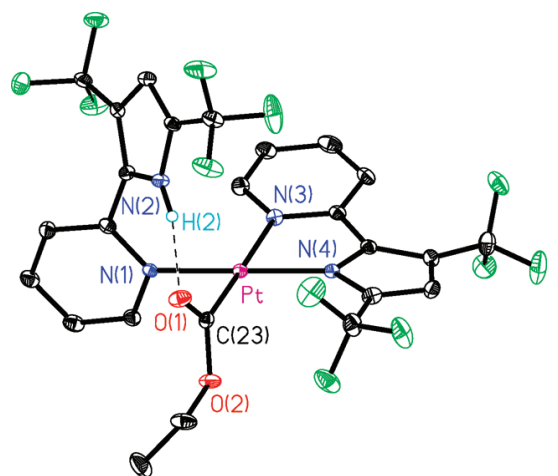

Figure 4. ORTEP diagram of 6 with ellipsoids shown at 25\% probability level; selected bond distances: $\mathrm{Pt}-\mathrm{N}(1)=2.037(4) ; \mathrm{Pt}-\mathrm{N}(3)=2.092(5)$; $\mathrm{Pt}-\mathrm{N}(4)=2.013(5) ; \mathrm{Pt}-\mathrm{C}(23)=1.976(6) ; \mathrm{O}(1)-\mathrm{C}(23)=1.214(7) ;$ $\mathrm{O}(2)-\mathrm{C}(23)=1.339(7) ; \mathrm{O}(2)-\mathrm{C}(24)=1.467(8) \AA$. 
Chen et al.

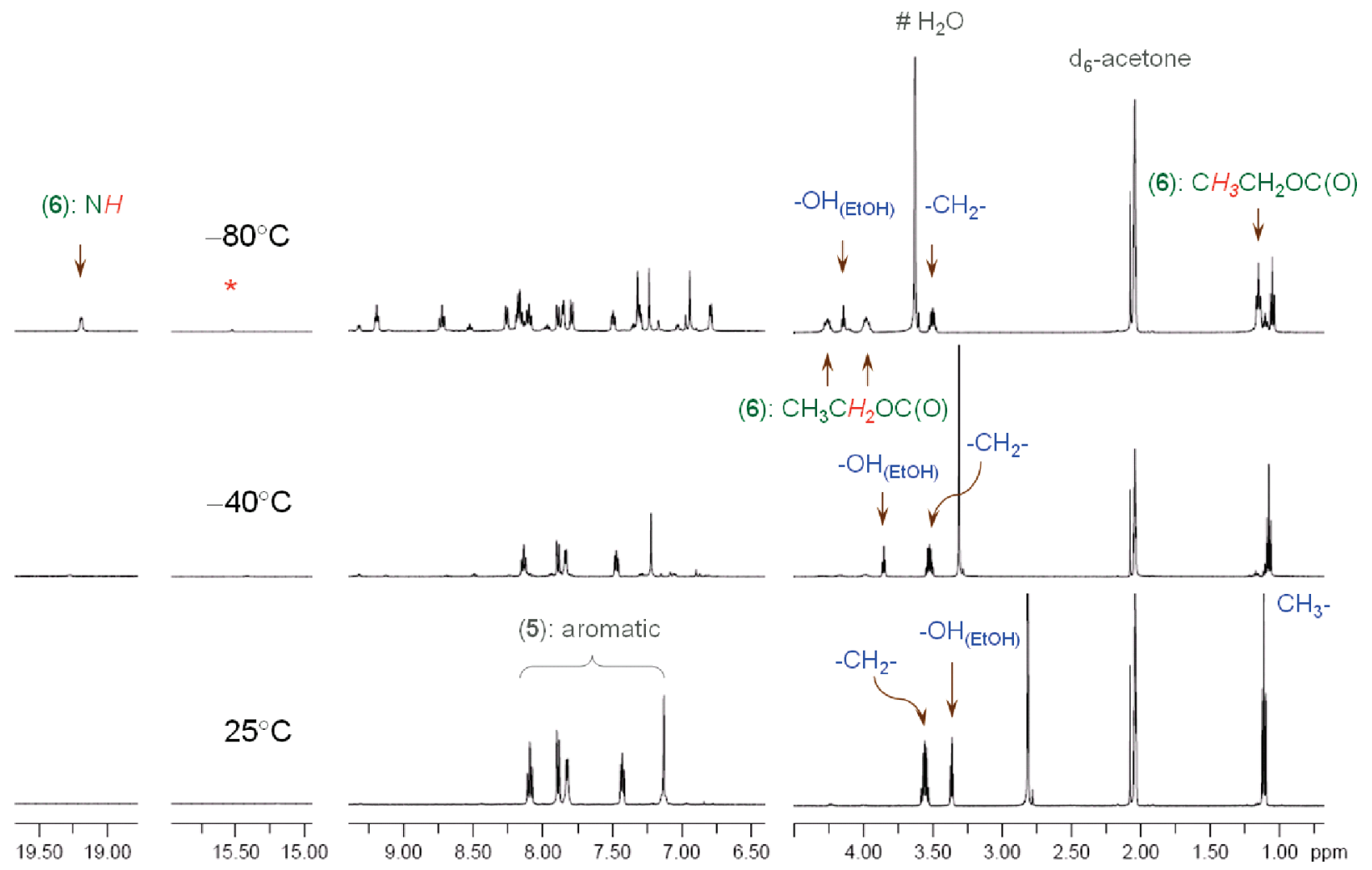

Figure 5. Variable temperature ${ }^{1} \mathrm{H}$ NMR spectra of $\mathbf{6}$ in $d_{6}$-acetone solution; the asterisk indicates the signals of an isomer of $\mathbf{6}$, whereas the signals of free ethanol are indicated in blue.

Table 2. Product Ratio Obtained from the Reactions of $\mathbf{5}$ with Various Alcohols at $-80^{\circ} \mathrm{C}^{a}$

\begin{tabular}{lccc}
\hline & unreacted $\mathbf{5}$ & $\mathrm{CO}_{2} \mathrm{R}$ complex & second isomer \\
\hline $\mathrm{MeOH}$ & $22 \%$ & $52 \%$ & $26 \%$ \\
$\mathrm{EtOH}$ & $28 \%$ & $59 \%$ & $13 \%$ \\
$\mathrm{PhCH}_{2} \mathrm{OH}$ & $43 \%$ & $43 \%$ & $14 \%$ \\
$i-\mathrm{PrOH}$ & $52 \%$ & $39 \%$ & $9 \%$
\end{tabular}

${ }^{a}$ The ratio was calculated using their relative ${ }^{19} \mathrm{~F}$ NMR signal intensities, whereas contributions from minor components are ignored.

derivative 7 , and the isomer of 7 in a ratio of $22 \%: 52 \%$ : $26 \%$ upon lowering the temperature to $-80{ }^{\circ} \mathrm{C}$. On similar reactions with benzyl alcohol and isopropyl alcohol, because of the failure in isolating the crystalline alkoxycarbonyl products, experiments were best conducted by the addition of equal amounts of alcohol to the $d_{6}$-acetone solution of $\mathbf{5}$ and then recording of the respective ${ }^{1} \mathrm{H}$ and ${ }^{19} \mathrm{~F}$ NMR spectra at both room temperature and $-80^{\circ} \mathrm{C}$. The resulting isomeric ratios depicted in Table 2 reveal the gradual decrease of reactivity upon switching from methanol, ethanol, benzyl alcohol, and to isopropyl alcohol. Finally, the reaction of $\mathbf{5}$ with reagents such as tert-butyl alcohol, phenol, or 1,1,1trifluoroethanol showed no formation of alkoxycarbonyl product, based on the NMR spectral pattern, whereas the respective reaction of $\mathbf{5}$ with diethylamine afforded instant sample decomposition and formation of black, intractable products.

\section{Conclusion}

In summary, we have designed a pyridyl pyrrolide platinum(II) 1 possessing an intrinsic steric hindrance to study its chemical reactivity and the associated reaction patterns toward the addition of selected $\mathrm{N}$ - and C-donors as well as nucleophilic attack by alcohol at the coordinated CO ligand. During the initial addition of donor ligands, the cleavage of one labile $\mathrm{Pt}-\mathrm{N}$ (pyridine) bond opens up the entire coordination framework, resulting in relief of internal strain and hence generating the necessary driving force to trigger the designated reaction. For reactivity studies, a total of four platinum(II) metal complexes were characterized with nucleophiles such as acetonitrile, pyridine, isocyanide, and even carbon monoxide. The novel $\mathrm{CO}$ addition $\mathbf{5}$ can react reversibly with ethanol in solution to afford ethoxycarbonyl $\mathbf{6}$; the latter is demonstrated by X-ray structural analysis and by corresponding variable temperature NMR studies. This reaction is interpreted in terms of a direct nucleophilic attack at the coordinated $\mathrm{CO}$ by free alcohol, rather than by a migratory insertion pathway. Apparently, the coordination of the pendant pyridyl ligand, detachment of pyrrolide from the platinum metal center induced by proton transfer, and the concomitant formation of internal hydrogen bonding between the pyrrole and alkxoycarbonyl groups are all crucial in maintaining the reaction stoichiometry as well as stabilizing the final product. From both fundamental and application viewpoints, the insights gained from this study could have significant implications for the design and preparation of more efficient metal catalysts for carbon monoxide activation.

Acknowledgment. This work was funded by the National Science Council of Taiwan, ROC, under grants NSC 93- 
2113-M-007-012 and NSC 93-2752-M-002-002-PAE, and the Natural Science and Engineering Research Council of Canada.

Supporting Information Available: X-ray crystallographic data files (CIF) of 1, 3, 4, and $6 ;{ }^{1} \mathrm{H}$ NMR spectra showing the gradual formation of $\mathbf{2}$ in acetone and acetonitrile mixture, $\mathrm{UV}-$ vis spectra during $\mathrm{CO}$ titration of $\mathbf{1}$; and the variable temperature ${ }^{19} \mathrm{~F}$ NMR spectra of $\mathbf{4}$ and $\mathbf{6}$. This material is available free of charge via the Internet at http://pubs.acs.org.

IC800117V 